\title{
Początki onkologii na Podkarpaciu
}

\author{
Jan Gawełko
}

Pierwszy dokument dotyczący powstania onkologii w Rzeszowie pochodzi z lipca 1952 roku; jest to pismo Ministerstwa Zdrowia w sprawie utworzenia stanowiska inspektora do spraw walki z rakiem oraz utworzenia Poradni Onkologicznej. Była to pierwsza jednostka onkologiczna w rejonie Podkarpacia. Poradnią kierowali kolejno: dr Eugeniusz Litwin, dr Wojciech Chabinka i — od 1961 r. — dr Józef Małek, który był jednocześnie organizatorem i pierwszym kierownikiem powstałej w maju 1962 r. Pracowni Rentgenoterapii. W grudniu 1963 roku utworzony został Wojewódzki Ośrodek Onkologiczny w Rzeszowie, składający się z Wojewódzkiej Przychodni Onkologicznej oraz Oddziału Onkologicznego, w którego strukturze funkcjonowały działy: radioterapii ogólnej, radioterapii ginekologicznej, chirurgii, pracownie rentgenoterapii, fizyki medycznej, gabinety radowe, dział dokumentacji i dział metodyczno-organizacyjny. W roku 1971 Ośrodek otrzymał z Instytutu Onkologii w Warszawie 550 mg radu. W 1975 roku, po reorganizacji, utworzono na jego bazie samodzielną jednostkę - Specjalistyczny Onkologiczny ZOZ, który w 1976 roku przekształcono w Wojewódzki Szpital Onkologiczny w Rzeszowie. Pod tą nazwą onkologia rzeszowska funkcjonowała do 1990 roku.

\section{Oncology in the Podkarpacie Region: the early years}

The first document referring to the organisation of oncological care in the region of Rzeszów province comes from 1952. The first oncological unit in the Rzeszów region - Provincial Oncological Dispensary started its activities on December 1952. In March 1961, dr Józef Małek became the Head of the Dispansery. He also directed the organisation of the first roentgenotherapy laboratory, who was ready for work on May, 1962. The Provincial Oncological Centre in Rzeszów was estabilished on 19-th December 1963. The Centre had several sections: general radiotherapy, gynecological raditherapy, surgery, roentgenotherapy lab, physics lab, radium rooms, docementation section and methodical and organisation section. In 1971, the Centre acquired 550 mg of radium for the curietherapy laboratory. In 1975 and 1976, the named was changed into Provincial Oncological Hospital in Rzeszów. Under above-mentioned name the oncological medical center in Rzeszów was working until 1990.

NOWOTWORY Journal of Oncology 2014; 64, 4: 346-352

Słowa kluczowe: Podkarpackie Centrum Onkologii, onkologia w Rzeszowie, ośrodki onkologiczne w Polsce

Udokumentowana historia rzeszowskiej onkologii rozpoczyna się w lipcu 1952 roku. Ministerstwo Zdrowia zwróciło się wówczas do Prezydium Wojewódzkiej Rady Narodowej w Rzeszowie o utworzenie stanowiska inspektora do spraw walki z rakiem oraz o zatrudnienie w tej roli dr. Eugeniusza Litwina'. W tym samym piśmie, opatrzonym datą 29 lipca, polecono utworzenie i uruchomienie $z$ dniem 1 grudnia 1952 roku Poradni Onkologicznej oraz pobranie 1000 egz. kart zgłoszenia nowotworu (ryc. 1).

Dr Eugeniusz Litwin, po demobilizacji w stopniu majora WP, pracował od 1 maja 1947 roku w Państwowym Instytucie Przeciwrakowym w Gliwicach. Był starszym asystentem,

'Zasób archiwalny Wojewódzkiego Szpitala Specjalistycznego (WSS)

w Rzeszowie. Akta osobowe nr 1407, k.6. 


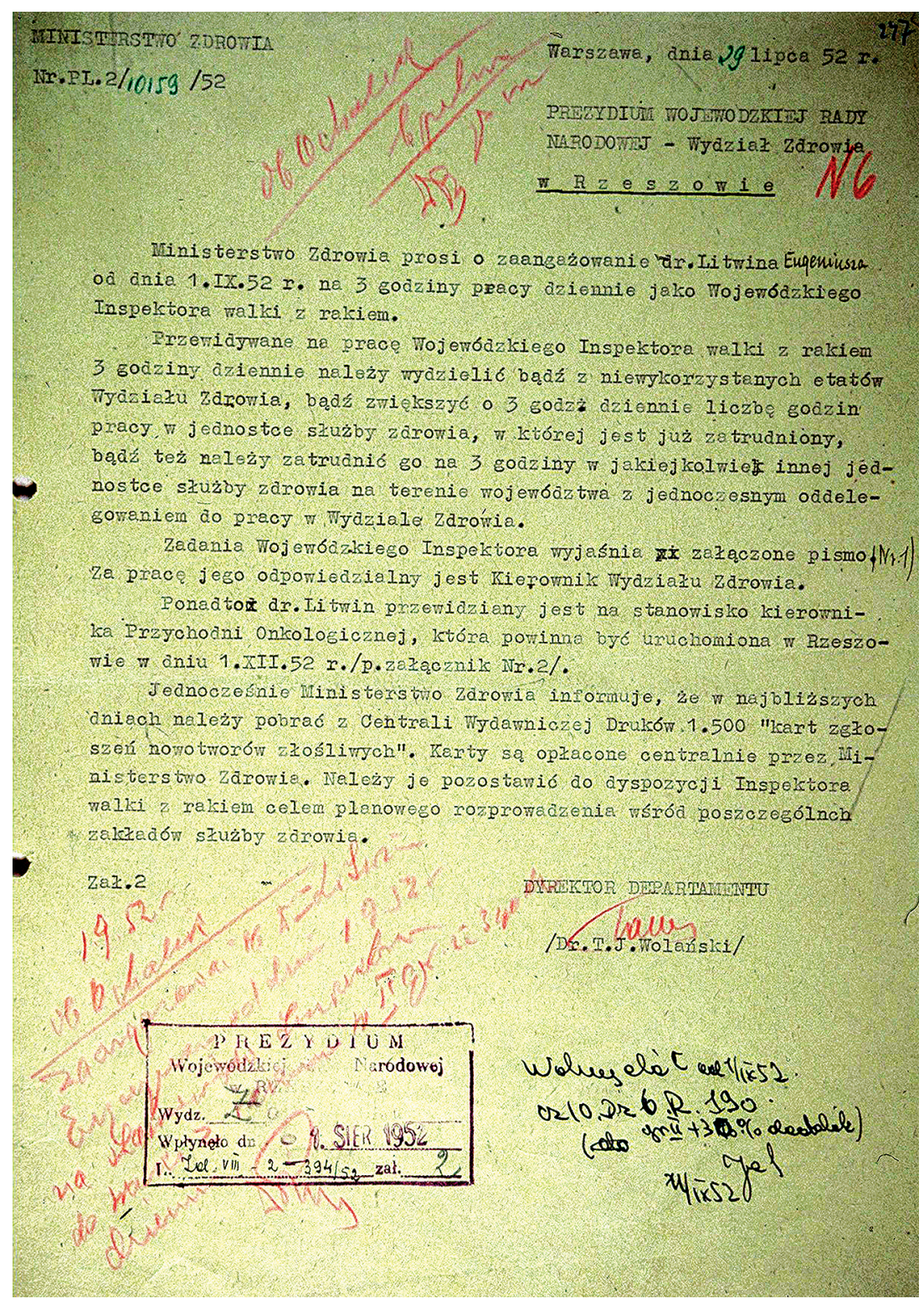

Rycina 1. Wniosek o powołanie „Wojewódzkiego Inspektora walki z rakiem” w Rzeszowie, rok 1952

kolejno: na sali rentgenoterapii ginekologicznej, na oddziale chirurgii, w zakładzie rentgenoterapii, ambulatorium ogólnym i ginekologicznym oraz w innych strukturach Instytutu². Pełnił również funkcję konsultanta urologa.

W zaświadczeniu z dnia 4 sierpnia 1952 roku dr Jeremi Święcki, ówczesny dyrektor Instytutu, stwierdził: „Dr Litwin odchodzi z Instytutu na własną prośbę w celu objęcia funkcji kierownika punktu onkologicznego w woj. rzeszowskim. Na stanowisko to jest w zupełności przygotowany"3.

Dr Litwin zatrudniony został jako inspektor do spraw walki z rakiem 1 września 1952 roku, natomiast Wojewódzka
Poradnia Onkologiczna rozpoczęła pracę 1 grudnia. Była to pierwsza jednostka onkologiczna na Rzeszowszczyźnie.

Obowiązki asystenta w Poradni pełniła dr Maria Machowska. Pracowała tam nieprzerwanie do listopada 1963 roku, uzyskując w międzyczasie specjalizację I i ll stopnia z chirurgii. Pracowała jednocześnie na Oddziale Chirurgii, ukończyła szereg kursów i szkoleń w tym również dla ordynatorów z zakresu chirurgii onkologicznej ${ }^{4}$.

W marcu 1955 roku, na wniosek dyrektora Instytutu Onkologii w Krakowie — doc. dr hab. Hanny Kołodziejskiej-Wertheim, Ministerstwo Zdrowia zwróciło się do Wydziału 


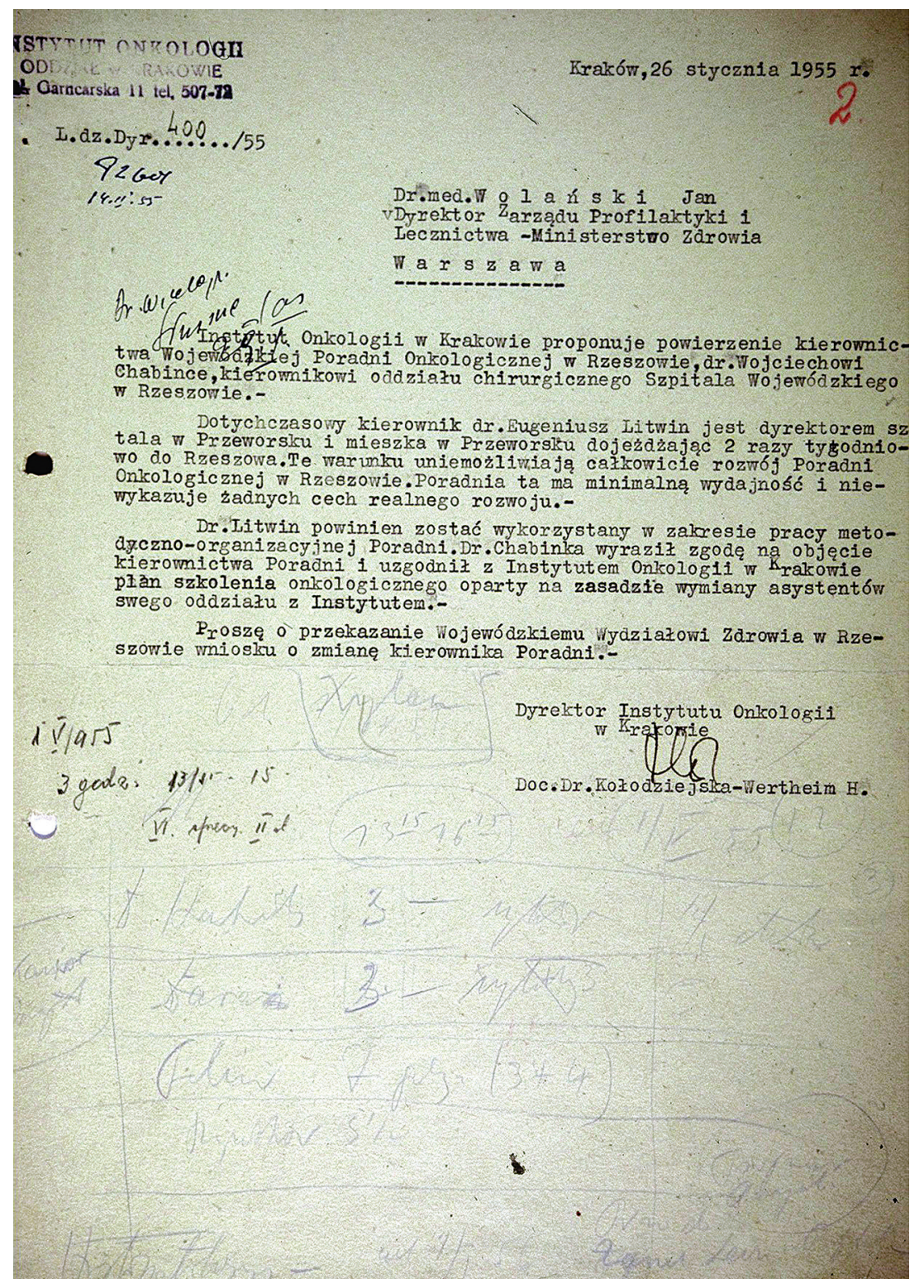

Rycina 2. Wniosek doc. Hanny Kołodziejskiej-Wertheim w sprawie powierzenia kierownictwa Wojewódzkiej Poradni Onkologicznej dr. Wojciechowi Chabince

Zdrowia Wojewódzkiej Rady Narodowej w Rzeszowie w sprawie jak najszybszego rozwoju Wojewódzkiej Poradni Onkologicznej oraz skierowania do niej dr. med. Wojciecha Chabinki (ryc. 2) ${ }^{5}$. Był on uprzednio zatrudniony na stanowisku adiunkta w Instytucie Onkologii w Krakowie, a 1 stycznia 1955 roku objął funkcję ordynatora Oddziału Chirurgii w Szpitalu Wojewódzkim w Rzeszowie ${ }^{6}$. Dr Wojciech Chabinka objął kierownictwo Poradni w kwietniu 1955 roku i już w czerwcu tego roku uczestniczył w naradzie kierowników Przychodni Onkologicznych, zorganizowanej w In-

${ }^{5}$ Doc. Hanna Kolodziejska-Wertheim była wieloletnim konsultantem

w zakresie onkologii dla województwa rzeszowskiego, por.: Skołyszewski J. Wspomnienie o prof. dr med. Hannie Kołodziejskiej-Wertheim (1914-2004). Nowotwory J Oncol 2004; 54: 587-88.

${ }^{6}$ Zasób archiwalny WSS w Rzeszowie. Akta osobowe nr 4366, k.2. stytucie Onkologii w Warszawie. Ten zasłużony dla miasta i województwa specjalista kierował Przychodnią do lutego 1961 roku, a funkcję ordynatora Oddziału Chirurgii pełnił do grudnia 1978 roku$^{7}$. Zasługi jego zostały uhonorowane Krzyżami: Kawalerskim i Oficerskim Orderu Odrodzenia Polski (ryc. 3).

W pierwszych latach swojej działalności Poradnia mieściła się w budynku Wojewódzkiej Przychodni Specjalistycznej przy ul. Hetmańskiej i przyjmowała około 600 pacjentów rocznie ${ }^{8}$. 


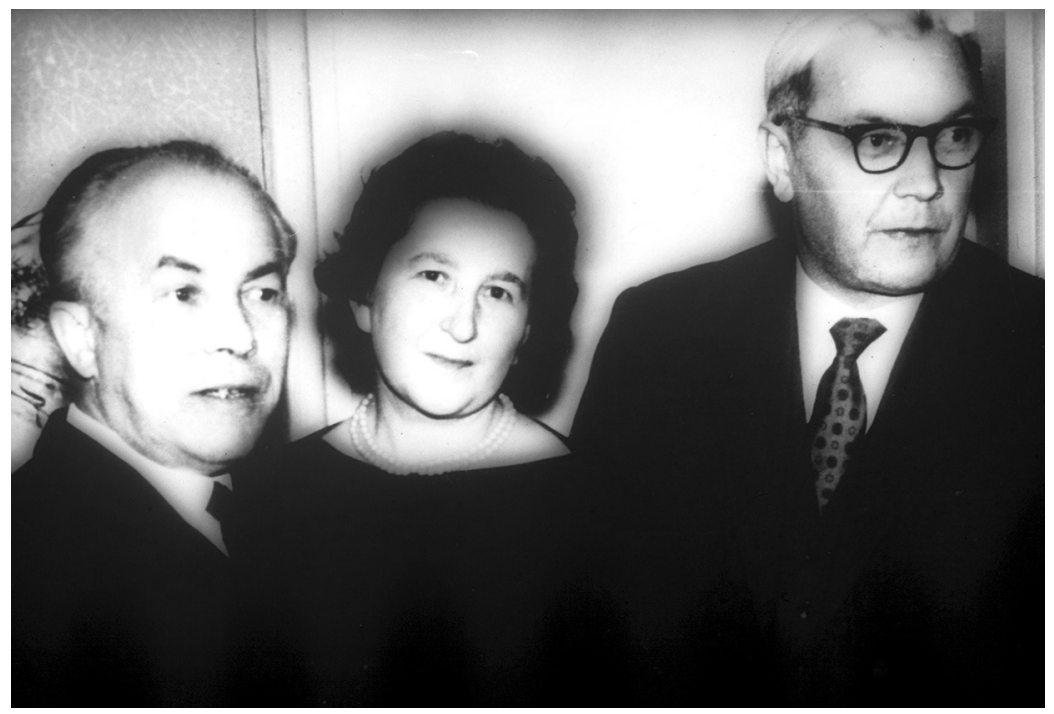

Rycina 3. Dr Wojciech Chabinka, od 1955 roku kierownik Wojewódzkiej Poradni Onkologicznej i dr Maria Machowska, zatrudniona w Poradni od 1952 roku

Od 1 marca 1961 roku kierownictwo Poradni objął dr Józef Małek (ryc. 4). Posiadał on specjalizację z zakresu radiologii oraz - według ówczesnego mianownictwa — onkologii (obecnie radioterapii). Oprócz pracy w Poradni kierował organizacją pierwszej w regionie Pracowni Rentgenoterapii ${ }^{9}$. Pracownia ta została uruchomiona 1 maja 1962 roku i początkowo mieściła się w zaadaptowanych pomieszczeniach obok Izby Przyjęć w budynku Szpitala Wojewódzkiego przy ul. Chopina. Do końca roku leczono tam 96 pacjentów i wykonano 2489 seansów rentgenoterapii ${ }^{10}$.

Pierwszy aparat do rentgenoterapii, typu „Skandia”, przekazany przez Oddział Instytutu Onkologii w Krakowie, miał stosunkowo niedużą wydajność, a czas napromieniania przekraczał 20 minut. Pracownia nie posiadała zaplecza łóżkowego, chorzy byli leczeni ambulatoryjnie, a w razie potrzeby - hospitalizowani w oddziałach Szpitala Wojewódzkiego w Rzeszowie.

Starania o dalszy rozwój onkologii w Rzeszowie znalazły pełne zrozumienie i poparcie zarówno u ówczesnego konsultanta wojewódzkiego — dr Janiny Kujawskiej z Instytutu w Krakowie, jak i u dyrektora tegoż Instytutu — prof. Hanny Kołodziejskiej-Wertheim oraz konsultanta krajowego ds. onkologii, a zarazem wicedyrektora Instytutu Onkologii w Warszawie - prof. Tadeusza Koszarowskiego ${ }^{11}$.W piśmie z sierpnia 1963 roku prof. Koszarowski deklarował pomoc zarówno w działaniach organizacyjnych, jak i w staraniach

\footnotetext{
${ }^{9}$ Zasób archiwalny WSS w Rzeszowie. Akta osobowe nr 9397, k. 2. ${ }^{10}$ Relacja dr. J. Małka...op. cit.

${ }^{11}$ Por.: Kołodziejska H. Pracowałam w Instytucie Onkologii. Nowotwory 1992; 42: 102-106, przedruk w: Towpik E. (red.) Materiały do historii Instytutu Radowego i Instytutu Onkolgii im. Marii Skłodowskiej-Curie w Warszawie - w 80 rocznicę otwarcia. Warszawa 2012, Polskie Towarzystwo Onkologiczne, s. 301-307.
}

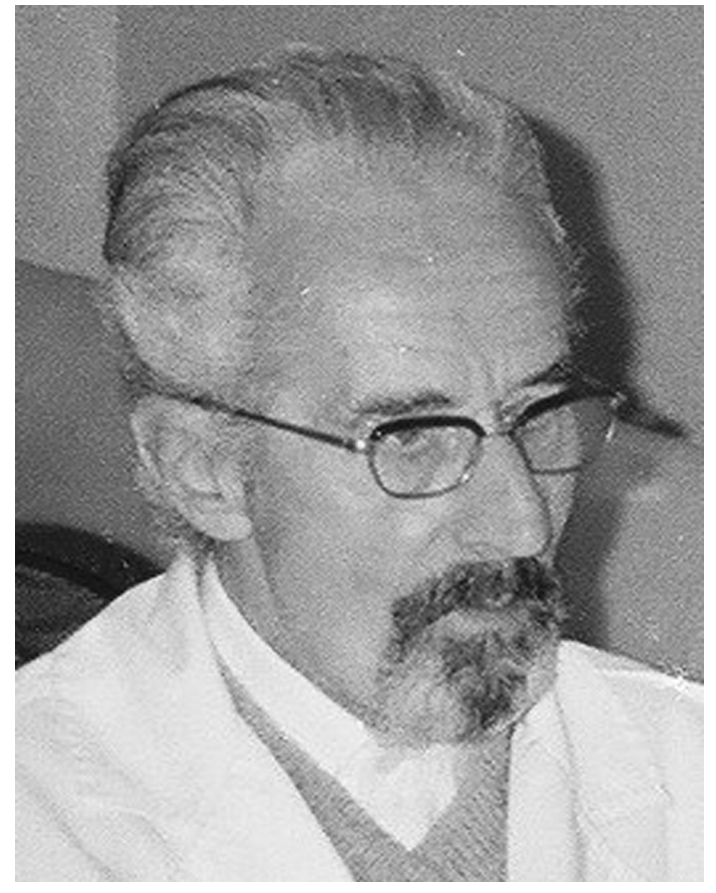

Rycina 4. Dr Józef Małek, kierownik Poradni od 1961 roku i organizator pierwszej Pracowni Rentgenoterapii w 1962 roku, wieloletni Dyrektor Wojewódzkiego Szpitala Onkologicznego w Rzeszowie

o aparaturę do rentgenoterapii ${ }^{12}$. Działania te zaowocowały wydaniem, dnia 19 grudnia 1963 roku, zarządzenia o tymczasowej strukturze organizacyjnej Wojewódzkiego Ośrodka Onkologicznego przy Szpitalu Wojewódzkim w Rzeszowie ${ }^{13}$.

\footnotetext{
12Pismo prof. T. Koszarowskiego do kierownika Wydziału Zdrowia Prezydium Wojewódzkiej Rady Narodowej, APR, PWRN, sygn. 21900.

${ }^{13}$ Maszynopis w archiwum PC.
} 


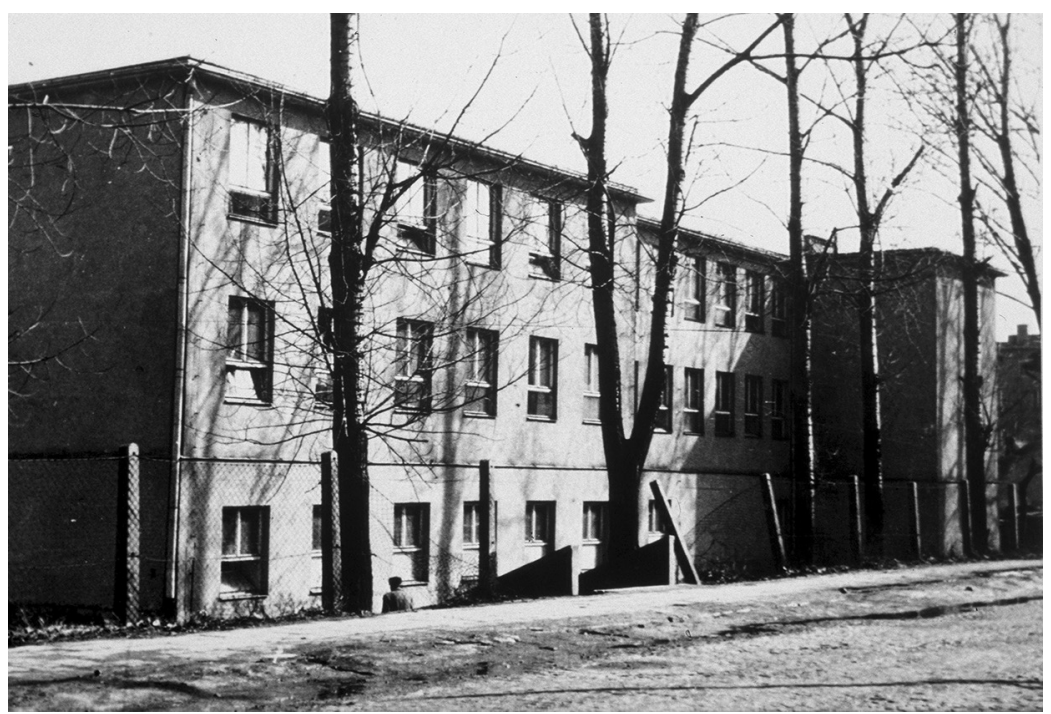

Rycina 5. Siedziba Wojewódzkiego Ośrodka Onkologicznego w Rzeszowie od 1964 roku

Zarządzenie to informowało, że Ośrodek jest podstawowąjednostką lecznictwa onkologicznego w województwie, pod względem administracyjnym podlega dyrekcji Szpitala Wojewódzkiego, a pod względem merytorycznym — Instytutowi Onkologii w Krakowie.

W ramach pomocy udzielanej przez krakowski Instytut przebywał w Rzeszowie ówczesny adiunkt — późniejszy wieloletni dyrektor Instytutu — prof. dr hab. Jan Skołyszewski, sprawując pod nieobecność dr. J. Małka kierownictwo Pracowni oraz planując i nadzorując leczenie napromienianiem.

Zachowana w archiwaliach „Tymczasowa Struktura Organizacyjna Wojewódzkiego Ośrodka Onkologicznego w Rzeszowie" zadziwia - z obecnej perspektywy 50 lat — kompleksowością ujęcia zagadnienia i kompetencją autorów ${ }^{14,15}$. Odwołuje się bezpośrednio do wytycznych Instytutu Onkologii w Warszawie w zakresie struktury, etatów oraz zagadnień szczegółowych.

Do zadań Ośrodka, oprócz rozpoznawania i leczenia chorób nowotworowych, zalicza m.in. działania w zakresie:

- wykrywania i leczenia stanów przedrakowych oraz współudziału w akcjach profilaktycznych na terenie województwa,

- udzielania pomocy fachowej w organizowaniu walki $z$ rakiem na terenie województwa,

- szkolenia lekarzy onkologów, doszkalania a z zakresu onkologii lekarzy innych specjalności, doszkalania pozostałego personelu fachowego ośrodka i placówek terenowych.
Zadanie „prowadzenia sprawozdawczości w zakresie schorzeń nowotworowych na terenie województwa" skutkuje po dziś dzień 50-letnią działalnością Podkarpackiego Rejestru Nowotworów - jednego z najlepszych w Polsce.

Dnia 1 kwietnia 1964 roku oddano na siedzibę Wojewódzkiego Ośrodka Onkologicznego budynek przy ul. Leszczyńskiego 1, do którego dobudowano skrzydło, mieszczące zespół 4 pracowni rentgenoterapii oraz Wojewódzką Poradnię Onkologiczną (ryc. 5). Nie był to budynek nowy, w latach międzywojennych mieścił się w nim szpital wyznaniowy, w czasie wojny szpital niemiecki, a po wojnie - Szpital MSW. Budowa wspomnianego skrzydła w 1964 r. była w ciągu niemal 25 lat jedyną inwestycją zwiększającą infrastrukturę i bazę lokalową rzeszowskiej onkologii.

Powstałym w 1964 roku Ośrodkiem, w myśl cytowanej już „,Struktury...", kierował specjalista II stopnia z zakresu onkologii; był on jednocześnie kierownikiem Oddziału Onkologii. Oddział ten miał bardzo rozbudowaną strukturę — w jego skład wchodziły działy: radioterapii ogólnej, radioterapii ginekologicznej, chirurgii, pracownia rentgenoterapii, pracownia fizyki, gabinety radowe, dział dokumentacji oraz dział metodyczno-organizacyjny. Oprócz Oddziału w skład Ośrodka wchodziła Wojewódzka Przychodnia Onkologiczna z 3 gabinetami specjalistycznymi. Dzięki staraniom dr. Józefa Małka Ośrodek rozwijał się, i w 1966 roku był już wyposażony w 3 aparaty do rentgenoterapii: Philips, Skandia i RUM ${ }^{16,17}$.

W latach 60. i 70. ubiegłego wieku Ośrodek, posiadający 3 aparaty oraz pracownię curieterapii, był znaczącym

\footnotetext{
${ }^{16}$ Rozpracowanie wniosków i zaleceń specjalistów wojewódzkich. APR PWRN, sygn. 21809

${ }^{17}$ Zjazdy, narady, konferencje i odprawy konsultantów wojewódzkich. Informacja prof.H. Kołodziejskiej-Wertheim o stanie sieci onkologicznej w woj. rzeszowskim APR, PWRN, sygn. 21814.
}

\footnotetext{
${ }^{14}$ Tymczasowa Struktura Organizacyjna...op. cit.

${ }^{15}$ Pismo prof. T. Koszarowskiego... op. cit.
} 


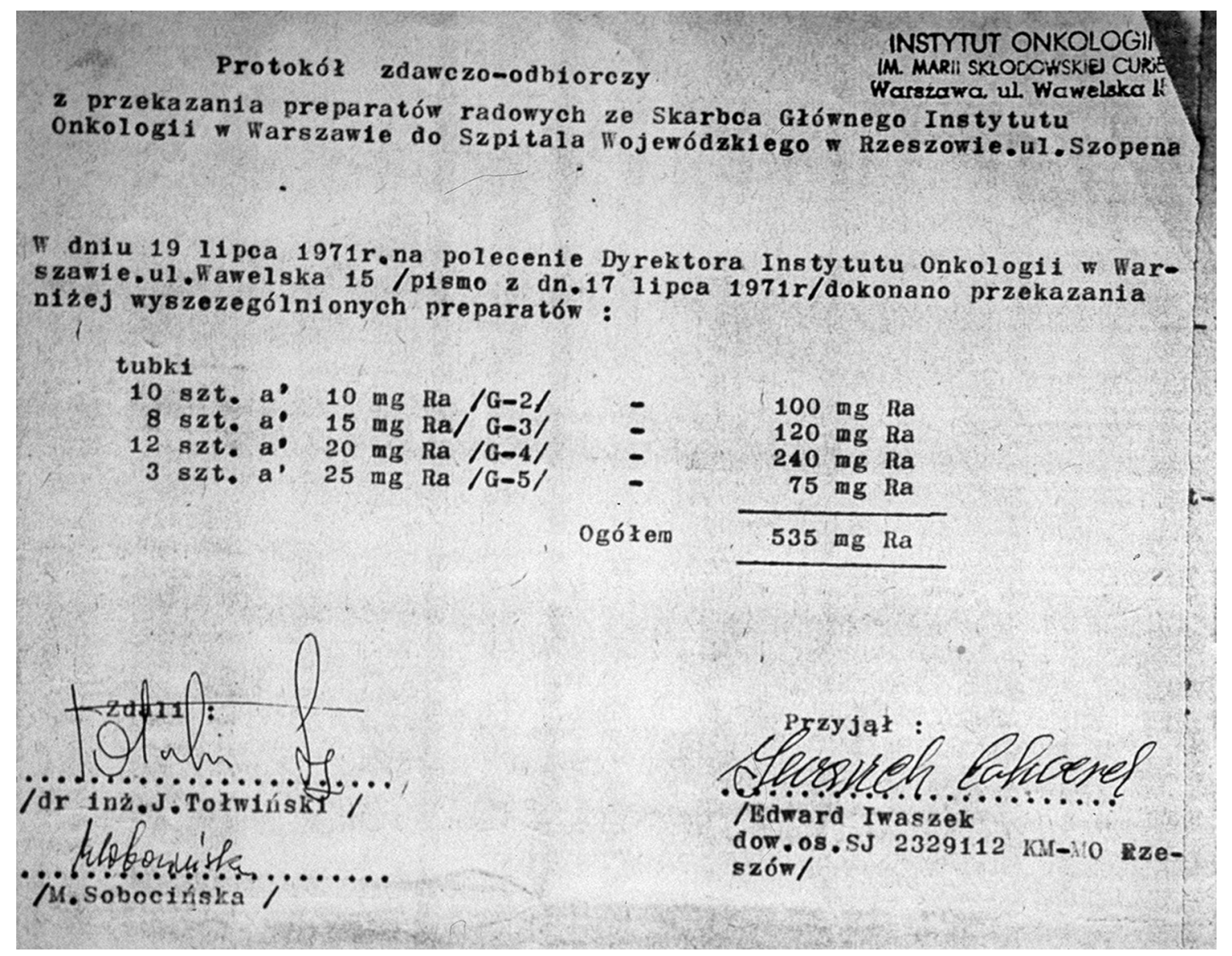

Rycina 6. Protokół przekazania radu z Instytutu Onkologii w Warszawie

punktem na onkologicznej mapie Polski. Liczba wykonywanych seansów szybko rosła, przekraczając w samym tylko 1968 roku 15 000. W wystąpieniu adresowanym do władz wojewódzkich prof. Hanna Kołodziejska-Wertheim — jako konsultant wojewódzki - jednoznacznie sygnalizowała potrzebę dalszej rozbudowy siedziby onkologii i dalszego rozwoju radioterapii ${ }^{18}$. Plany te obejmowały budowę nowego budynku dla potrzeb onkologii oraz wyposażenie go w terapię megawoltową.

Zanim wizja ta ziściła się, pracownia rentgenoterapii dobrze zasłużyła się społeczeństwu Podkarpacia. Działała przez 51 lat, służąc do celów terapii powierzchownej jeszcze w dobie teleterapii megawoltowej. Ostatni aparat — uzyskany w 1990 roku (Stabilipan) — zdemontowano w 2012 roku. Przez ponad 51 lat zastosowano rentgenoterapię u ponad 20 tysięcy pacjentów, wykonując ponad 600 tysięcy seansów rentgenoterapii ${ }^{19}$.

Istotną kartę w dziejach rzeszowskiej onkologii zapisała curieterapia, a następnie — brachyterapia. Zagadnienie to sygnalizowała już w 1968 roku prof. Hanna Kołodziejska-

\footnotetext{
${ }^{18}$ Ibidem.

${ }^{19}$ Gawełko J. Onkologia na Podkarpaciu wczoraj i dziś. Konferencja Naukowa: Onkologia na Podkarpaciu 1952-2011, Rzeszów, 27 września 2011.
}

-Wertheim jako konsultant wojewódzki ${ }^{20}$. Inspirowany jej stanowiskiem ówczesny dyrektor Szpitala wystąpił w sierpniu 1968 roku do Fundacji im. Jakuba hr. Potockiego z prośbą o pomoc w tym zakresie.

W archiwach brak jest informacji odnośnie odpowiedzi, natomiast w maju 1971 roku Wojewódzki Inspektor Sanitarny wydał zgodę na prowadzenie pracowni izotopowej klasy „Z" w Wojewódzkim Ośrodku Onkologicznym w Rzeszowie, a 30 czerwca tegoż roku Centralne Laboratorium Ochrony Radiologicznej wydało zezwolenie Nr J-616 na nabywanie i użytkowanie substancji promieniotwórczych ${ }^{21}$.

W oparciu o to zezwolenie w dniu 19 lipca 1971 roku, na polecenie dyrektora Instytutu Onkologii w Warszawie (funkcję tę pełnił wówczas prof.Władysław Jasiński), wydano ze skarbca głównego Instytutu Onkologii i przekazano do Rzeszowa 33 sztuki tubek radowych o zawartości od 10 do 25 mg radu 226 - łącznie 535 mg (ryc. 6) ${ }^{22}$. Według niepotwierdzonej dokumentami ustnej informacji przekazywanej przez zatrudnionych w tym czasie pracowników — rad ten

\footnotetext{
${ }^{20}$ Kołodziejska-Wertheim H. Sprawozdania specjalistów wojewódzkich. Protokoły z kontroli (1968). APR, PWRN, sygn. 21817.

${ }^{21}$ Oryginał zezwolenia w archiwum PCO.

${ }^{22}$ Oryginał protokołu przekazania $\mathrm{w}$ archiwum PCO.
} 


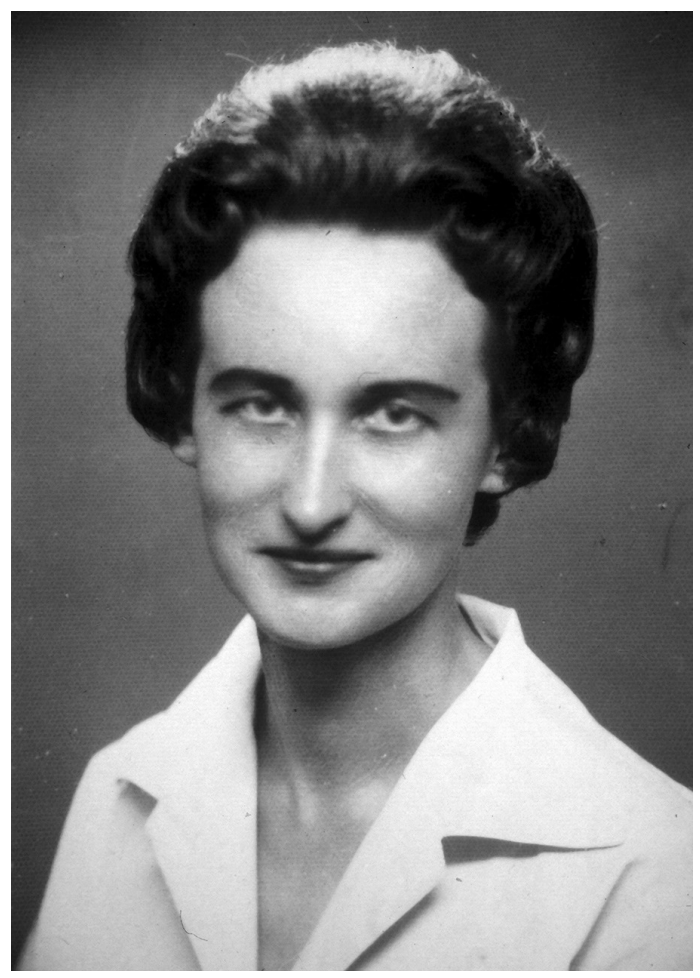

Rycina 7. Dr Krystyna Małek-Zielińska, lekarka Poradni Onkologicznej od 1960 roku, pierwsza ordynator Oddziału Radioterapii

miał być w swoim czasie zakupiony ze środków Fundacji im. Jakuba hr. Potockiego ${ }^{23}$.

Wyposażenie Pracowni zaprojektowane zostało przez ówczesnego ordynatora Oddziału Ginekologii Onkologicznej dr. n. med. Ryszarda Palczaka, który otrzymał na nie świadectwo patentowe. Ładunki radowe służyły chorym aż do 1989 roku, kiedy to zostały zastąpione przez cez 137. Leczono nimi ponad 2400 chorych $^{24}$.

Rozwój ośrodka objął również Wojewódzką Przychodnię Onkologiczną. W 1960 roku pracę w Poradni rozpoczęła dr Krystyna Małek-Zielińska (ryc. 7). W latach 1961-1963 przebywała ona na stypendium specjalizacyjnym w Instytucie Onkologii w Krakowie, po czym ponownie podjęła pracę w Przychodni25.

Po odejściu do Oddziału Chirurgii dr. Chabinki i dr Machowskiej pracę Przychodni organizowali dr Józef Małek idr Krystyna Małek-Zielińska.W 1961 roku dołączyła do nich dr Władysława Garska jako konsultant histopatolog. W późniejszych latach prof. dr hab. Władysława Garska kierowała Zakładem Patomorfologii Instytutu Medycyny Klinicznej w Rzeszowie.

\footnotetext{
${ }^{23}$ Nie ma potwierdzenia tego faktu w archiwum Fundacji - informacja obecnego sekretarza Rady Fundacji im. Jakuba hr. Potockiego prof. Edwarda Towpika.

${ }^{24}$ Gawełko J. op. cit.

${ }^{25}$ Zasób archiwalny WSS w Rzeszowie. Akta osobowe nr 1534 k.2,3.
}

Rozwój rzeszowskiej onkologii w latach 70., 80. i 90. jest związany z działalnością tego Instytutu, który jako jednostka Akademii Medycznej w Krakowie kształcił studentów lat klinicznych. Kształcenie odbywało się na IV, V i VI roku Wydziału Lekarskiego, w liczbie po 50 studentów na roku ${ }^{26}$. Szkolenie studentów V roku w jednostkach Wojewódzkiego Szpitala Onkologicznego z zakresu onkologii wykazywane jest w raportach dr. Małka jako konsultanta wojewódzkiego aż do 1989 roku ${ }^{27-32}$. W realizacji programu kształcenia brali udział pracownicy naukowi kierujący oddziałami klinicznymi i zakładami wchodzącymi w skład Instytutu, m.in.: prof. dr hab. Tadeusz Zaczek, prof. dr hab. Andrzej Bętkowski, prof. dr hab. Stanisław Hady, prof. dr hab. Tadeusz Szmigiel, prof. dr hab. Kazimierz Ulewicz, prof. dr hab. Lesław Grzegorczyk, prof. dr hab. Ryszard Korczowski.

W 1975 roku Ośrodek Onkologii, stosownie do zarządzenia nr 166/75 wojewody rzeszowskiego, został wydzielony ze struktury Wojewódzkiego Szpitala Zespolonego w Rzeszowie jako Onkologiczny Specjalistyczny $Z Z^{33}$.

Następnie, zgodnie z zarządzeniem wojewody rzeszowskiego nr 101 z 19 października 1976 roku, został przemianowany na Wojewódzki Szpital Onkologiczny w Rzeszowie $^{31}$.Zakres działania Szpitala, określony przez Statut, obejmował 17 zagadnień i był o wiele szerszy niż dotychczasowy zakres działania Ośrodka ${ }^{34}$. Struktura Szpitala obejmowała: Oddział Onkologii Ogólnej, Oddział Ginekologii Onkologicznej z pododdziałem brachyterapii, Zakład Rentgenoterapii oraz Pracownie: Rentgenodiagnostyki, Histopatologii, Fizyki i Ochrony Radiologicznej. Oprócz tego w skład Szpitala wchodziły: Wojewódzka Poradnia Onkologiczna oraz — w ramach działu administracyjno-finansowego — sekcja statystyki i dokumentacji medycznej, prowadząca rejestr nowotworów. W strukturze tej Wojewódzki Szpital Onkologiczny przetrwał do 1990 roku.

\section{Podziękowanie}

Autor dziękuje p. mgr Annie Czop, Kierownikowi Działu Zarządzania ZasobamiLudzkimi WojewódzkiegoSzpitala Specjalistycznego im. F. Chopina w Rzeszowie za pomoc w uzyskaniu danych z Zasobu Archiwalnego WSS.

\section{Dr med. Jan Gawełko}

Instytut Pielęgniarstwa i Nauk o Zdrowiu

Uniwersytet Rzeszowski

ul. Kopisto 2 a, 35-959 Rzeszów

e-mail:jangawelko@o2.pl

\footnotetext{
${ }^{26}$ Grzegorczyk L. Nauki medyczne i o wychowaniu fizycznym. W: Rapor o stanie i perspektywach rozwoju rzeszowskiego ośrodka naukowego, Kraków 1981, s. 131-147.

${ }^{27}$ Małek J. Roczne sprawozdanie konsultanta ds. onkologii woj.

rzeszowskiego - 1984 r., archiwum PCO.

${ }^{28}$ Ibidem, $1985 \mathrm{r}$.

${ }^{29} \mathrm{lbidem}, 1986 \mathrm{r}$.

30 lbidem, $1987 \mathrm{r}$.

${ }^{31}$ Ibidem, $1988 \mathrm{r}$.

${ }^{32}$ Ibidem, $1989 \mathrm{r}$.

${ }^{33}$ Kopia w archiwum PCO.

${ }^{34}$ Kopia $w$ archiwum PCO.
} 